\title{
PENYULUHAN HUKUM TENTANG URGENSI PENDAFTARAN HKI PADA GURU SD MUHAMMADIYAH 8 DAU
}

\author{
Yohana Puspitasari Wardoyo ${ }^{1}$, Belinda Dewi Regina ${ }^{2}$, Arinta Rezty $\mathbf{W}^{3}$ \\ ${ }^{1)}$ Program Studi Ilmu Hukum, Fakultas Hukum, Universitas Muhammadiyah Malang \\ ${ }^{2,3)}$ Program Studi PGSD, Fakultas Keguruan dan Ilmu Pendidikan, Universitas Muhammadiyah Malang \\ e-mail: yohanawardoyo@umm.ac.id, belindadewi@umm.ac.id, arinta@umm.ac.id
}

\begin{abstract}
Abstrak
Guru adalah pendidik profesional dengan tugas utama mendidik, mengajar, membimbing, mengarahkan, melatih, menilai, dan mengevaluasi peserta didik pada pendidikan anak usia dini jalur pendidikan formal, pendidikan dasar, dan pendidikan menengah sebagaimana diatur dalam pasal 1 ayat (1) Undang-Undang Nomor 14 Tahun 2015 Tentang Guru dan Dosen. Guru dapat mengembangkan kreativitasnya dalam melaksanakan transfer knowledge kepada para siswa untuk mempermudah proses belajar mengajar salah satunya dengan menciptakan suatu karya sebagai media pembelajaran. Adapun karya yang dapat dihasilkan oleh guru antara lain membuat modul, buku pelajaran, poster, bahkan membuat kreasi karya seni seperti lagu, tarian, motif seni batik, seni rupa, drama musikal dan lain sebagainya. Namun dibalik kreativitas tersebut tidak pernah terpikirkan oleh guru bahwa karya yang dihasilkan sesungguhnya merupakan Hak Kekayaan Intelektual (HKI). Terdapat beberapa macam peraturan yang mengatur HKI salah satunya adalah Undang-Undang Nomor 28 Tahun 2014 Tentang Hak Cipta. Pengabdian dilakukan pada guru SD Muhammadiyah 8 Dau, Kabupaten Malang oleh itu diperlukan penyuluhan Hukum Tentang Urgensi Pendaftaran Hak Cipta Atas Suatu Karya.
\end{abstract}

Kata kunci: Penyuluhan Hukum, Hak Cipta, Karya, Guru

\begin{abstract}
Teachers are professional educators with the main task of educating, teaching, guiding, directing, training, assessing and evaluating students in early childhood education through formal education, basic education and secondary education as regulated in article 1 paragraph (1) of the Law Number 14 of 2015 concerning Teachers and Lecturers. Teachers can develop their creativity in carrying out knowledge transfer to students to facilitate the teaching and learning process, one of which is by creating a work as a learning medium. The works that can be produced by the teacher include making modules, textbooks, posters, and even making art creations such as songs, dances, batik art motifs, fine arts, musical dramas and so on. However, behind this creativity, the teacher never thought that the work that was produced was actually an intellectual property right (HKI). There are several kinds of regulations that regulate IPR, one of which is Law Number 28 of 2014 concerning Copyright. The service is carried out to teachers of SD Muhammadiyah 8 Dau, Malang Regency. Therefore, legal counseling on the Urgency of Copyright Registration for a Work is needed.
\end{abstract}

Keywords: Legal Education, Copyrights, Works, Teachers

\section{PENDAHULUAN}

Setiap orang dianggap tahun hukum. Tidak peduli apakah orang tersebut tinggal di jantung kota atau jauh di pelosok pedesaan. Tidak jadi soal apakah orang tersebut lulusan fakultas hukum atau fakultas teknik. Ketika orang yang sama berhadapan dengan hukum, maka ia tak bisa menggunakan dalil bahwa ia tidak mengetahui adanya peraturan tertentu. Oleh karena itu perlu dikakukan peningkatan kesadaran hukum dengan penyuluhan hukum secara terus menerus sampai subyek/peserta merasa paham dan menyadari serta taat hukum. Rendahnya kesadaran hukum dapat disebabkan oleh kurangnya sosialisasi regulasi, edukasi, juga terbatasnya akses informasi. Berdasarkan Peraturan Menteri Hukum dan HAM No. M.01-PR.08.10 Tahun 2006 tentang Pola Penyuluhan Hukum Penyuluhan Hukum adalah salah satu kegiatan penyebarluasan informasi dan pemahaman terhadap norma hukum dan peraturan perundang-undangan yang berlaku. Tujuannya, 
untuk mewujudkan dan mengembangkan kesadaran hukum masyarakat sehingga tercipta budaya hukum dalam bentuk tertib atau patuh terhadap norma hukum dan perundang-undangan.

Pada pengabdian kali ini penulis melakukan penyuluhan hukum hak kekayaan intelektual dengan tema urgensi pendaftaran kekayaan intelektual atas suatu karya kepada guru-guru SD Muhammadiyah 8 DAU, Kabupaten Malang. Guru adalah pendidik profesional dengan tugas utama mendidik, mengajar, membimbing, mengarahkan, melatih, menilai, dan mengevaluasi peserta didik pada pendidikan anak usia dini jalur pendidikan formal, pendidikan dasar, dan pendidikan menengah sebagaimana diatur dalam pasal 1 ayat (1) Undang-Undang Nomor 14 Tahun 2015 Tentang Guru dan Dosen. Dalam proses Pendidikan, guru merupakan salah satu komponen yang mempunyai andil besar dalam mencerdaskan kehidupan Bangsa, karena sebagai pengajar atau pendidik guru mempunyai kewajiban mendidik siswanya menjadi seorang yang berakhlak mulia, berkepribadian yang baik, bertanggung jawab dan berilmu pengetahuan.

Guru dapat mengembangkan kreativitasnya dalam melaksanakan transfer knowledge kepada para siswa untuk mempermudah proses belajar mengajar salah satunya dengan menciptakan suatu karya sebagai media pembelajaran. Adapun karya yang dapat dihasilkan oleh guru antara lain membuat modul, buku pelajaran, poster, bahkan membuat kreasi karya seni seperti lagu, tarian, motif seni batik, seni rupa, drama musikal dan lain sebagainya. Namun dibalik kreativitas tersebut tidak pernah terpikirkan oleh guru bahwa karya yang dihasilkan sesungguhnya merupakan Hak Kekayaan Intelektual (HKI). Terdapat beberapa macam peraturan yang mengatur HKI salah satunya adalah Undang-Undang Nomor 28 Tahun 2014 Tentang Hak Cipta.

Hak Cipta juga merupakan bagian dari kekayaan intelektual di bidang ilmu pengetahuan, seni, dan sastra kepada para guru terkait pentingnya pendaftaran hak cipta atas suatu karya. Pendaftaran Hak Cipta sendiri diharapkan mampu memberikan keamanan serta menjaga eksklusivitas karya yang dhasilkan agar tidak ada tindakan penyalahgunaan maupun plagiarism serta melindungi hak ekonomi dari para kreator, dengan adanya pendaftaran hak cipta atas suatu karya diharapkan tidak ada pihak-pihak yang secara tidak bertanggung jawab memakai karya milik orang lain secara bebas, termasuk karya ciptaan yang diciptakan oleh guru dalam rangka mempermudah proses belajar mengajar.

Berdasarkan hasil observasi pada SD Muhammadiyah 8 Dau, Kabupaten Malang, terdapat permasalahan, yaitu $100 \%$ guru-guru tidak memiliki pengetahuan tentang HKI, khususnya Hak Cipta padahal para guru sering membuat kreasi pembelajaran namun tidak memiliki pengetahuan tentang Hak Cipta sebagaimana diatur dalam Undang-Undang Nomor 28 Tahun 2014 Tentang Hak Cipta. Solusi yang ditawarkan oleh pengabdi terhadap permasalahan di atas yaitu penyuluhan hukum tentang Urgensi Pendaftaran Hak Cipta Atas Suatu Karya dengan memberikan materi HKI secara umum, jenis-jenis ciptaan yang dilindungi, urgensi pendaftaran hak cipta, tata cara pendaftaran hak cipta. Target dalam pengabdian ini adalah mitra memiliki pemahaman terhadap jenis-jenis ciptaan yang dilindungi, urgensi pendaftaran hak cipta, tata cara pendaftaran hak cipta.

Tujuan dari pengabdian ini adalah memberikan penyuluhan kepada bapak ibu guru SD 8 DAU, terkait pendaftaran Hak Cipta Atas suatu karya.

\section{METODE}

Metode yang digunakan oleh pengabdi adalah:

1. Metode ceramah tatap muka dengan memberikan materi, jenis-jenis ciptaan yang dilindungi, urgensi pendaftaran hak cipta, tata cara pendaftaran hak cipta.

2. Diskusi tanya jawab

3. Pendampingan pendaftaran hak cipta

\section{HASIL DAN PEMBAHASAN}

Hak cipta lahir atas kreasi pencipta. Kreasi yang muncul dari "olah pikir dan "olah hati". Atau dalam terminologi antropologi, hak yang lahir dari cipta, rasa dan karsa manusia. Oleh karena itu, hak cipta haruslah benar-benar lahir dari kreativitas manusia, bukan yang telah ada di luar aktivitas atau di luar hasil kreativitas manusia. Kreativitas dan aktivitas manusia menjadi kata kunci dalam kelahiran atau kemunculan hak cipta. Itu jugalah sebabnya hak cipta disebut sebagai hak ekslusif (exlusive rights). Hanya manusia yang melakukan "olah otak dan olah hati" yang dapat melahirkan hak cipta. Hasil olah otak dan olah hati itu berupa benda tidak berwujud meliputi 
ilmu pengetahuan, seni dan sastra itu tidak dalam bentuk nyata (wujud dan konkret), tetapi dalam bentuk immateriil. HKI hanya akan mempunyai arti ekonomi apabila dijelmakan oleh pemiliknya dalam bentuk ciptaan atau invensi untuk dapat digunakan oleh pengguna. Pemanfaatan hak kekayaan intelektual dapat juga dialihkan kepada pihak lain melalui lisensi sehingga ciptaan atau invensi itu dapat dinikmati oleh oleh konsumen dalam lingkup kawasan yang lebih luas secara nasional dan/atau internasional. Lisensi adalah pemberian izin secara tertulis kepada pihak lain untuk memetik manfaat ekonomi dari suatu Hak Kekayaan Intelektual seseorang.

Hak Cipta juga merupakan bagian dari kekayaan intelektual di bidang ilmu pengetahuan, seni, dan sastra. Jenis ciptaan yang dilindungi sebagaimana diatur dalam pasal 40 Undang-Undang Nomor 28 Tahun 2014 Tentang Hak Cipta, diantaranya: a.buku, pamflet, perwajahan karya tulis yang diterbitkan, dan semua hasil karya tulis lainnya; b. ceramah, kuliah, pidato, dan Ciptaan sejenis lainnya; c. alat peraga yang dibuat untuk kepentingan pendidikan dan ilmu pengetahuan; $d$. lagu dan/atau musik dengan atau tanpa teks; e. drama, drama musikal, tari, koreografi, pewayangan, dan pantomim; f. karya seni rupa dalam segala bentuk seperti lukisan, gambar, ukiran, kaligrafi, seni pahat, patung, atau kolase; g. karya seni terapan; h. karya arsitektur; i. peta; j. karya seni batik atau seni motif lain; k. karya fotografi; 1 . Potret; m. karya sinematografi; n. terjemahan, tafsir, saduran, bunga rampai, basis data, adaptasi, aransemen, modifikasi dan karya lain dari hasil transformasi; o. terjemahan, adaptasi, aransemen, transformasi, atau modifikasi ekspresi budaya tradisional; p. kompilasi Ciptaan atau data, baik dalam format yang dapat dibaca dengan Program Komputer maupun media lainnya; q. kompilasi ekspresi budaya tradisional selama kompilasi tersebut merupakan karya yang asli; r. permainan video; dan s. Program Komputer.

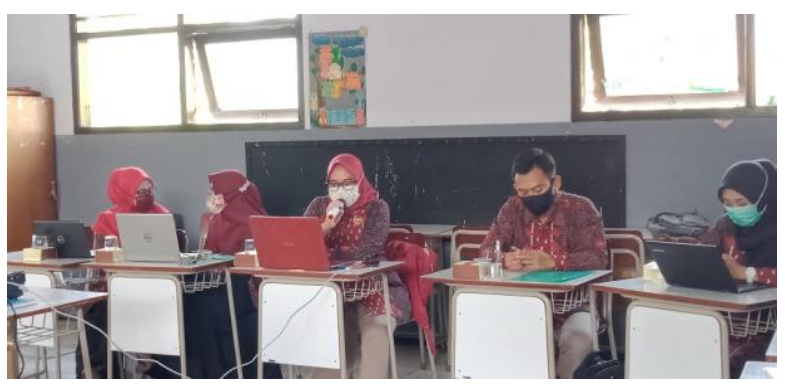

Penyuluhan tentang Urgensi Pendaftaran Hak Cipta

Prosedur pendaftaran hak cipta melalui Dirjen Kekayaan Intelektual Kementerian Hukum dan HAM Republik Indonesia dapat dilakukan secara online, Adapun persyaratan untuk mendaftarkan hak cipta antara lain:

1. Mengisi formulir pendaftaran ciptaan yang telah disediakan dalam bahasa Indonesia dan diketik rangkap tiga. Lembar pertama dari formulir tersebut ditandatangani di atas meterai

2. Surat permohonan pendaftaran ciptaan mencantumkan:

a. nama, kewarganegaraan dan alamat pencipta;

b. nama, kewarganegaraan dan alamat pemegang Hak Cipta; nama kewarganegaraan dan alamat kuasa; jenis dan judul ciptaan;

c. tanggal dan tempat ciptaan diumumkan untuk pertama kali;

d. uraian ciptaan (rangkap 3);

3. Surat permohonan pendaftaran ciptaan hanya dapat diajukan untuk satu ciptaan;

4. Melampirkan bukti kewarganegaraan pencipta dan pemegang Hak Cipta berupa fotokopi KTP atau paspor;

5. Apabila permohonan badan hukum, maka pada surat permohonanya harus dilampirkan turunan resmi akta pendirian badan hukum tersebut;

6. Melampirkan surat kuasa, bilamana permohonan tersebut diajukan oleh seorang kuasa, beserta bukti kewarganegaraan kuasa tersebut;

7. Apabila pemohon tidak bertempat tinggal di dalam wiliayah RI, maka untuk keperluan permohonan pendaftaran ciptaan ia harus memiliki tempat tinggal dan menunjuk seorang kuasa di dalam wilayah RI; 
8. Apabila permohonan pendaftaran ciptaan diajukan atas nama lebih dari seorang dan atau suatu badan hukum, maka nama-nama pemohon harus ditulis semuanya, dengan menetapkan satu alamat pemohon;

9. Apabila ciptaan tersebut telah dipindahkan, agar melampirkan bukti pemindahan hak;

10. Melampirkan contoh ciptaan yang dimohonkan pendaftarannya atau penggantinya.

\section{SIMPULAN}

Kegiatan Penyuluhan Hukum Tentang Urgensi Pendaftaran Hak Cipta Atas Suatu Karya Pada Guru SD Muhammadiyah 8 Dau, Kabupaten Malang, Jawa Timur untuk meningkatkan kapasitas pemahaman guru SD tentang HKI terutama Hak Cipta. Pendaftaran Hak Cipta sendiri diharapkan mampu memberikan keamanan serta menjaga eksklusivitas karya yang dhasilkan agar tidak ada tindakan penyalahgunaan maupun plagiarism serta melindungi hak ekonomi dari para kreator, dengan adanya pendaftaran hak cipta atas suatu karya diharapkan tidak ada pihak-pihak yang secara tidak bertanggung jawab memakai karya milik orang lain secara bebas, termasuk karya ciptaan yang diciptakan oleh guru dalam rangka mempermudah proses belajar mengajar.

\section{SARAN}

Perlu ada pendampingan pendaftaran Hak Cipta bagi guru yang memiliki Karya Cipta bagi guru yang memiliki karya/ ciptaan sebagaimana diatur dalam pasal 40 Undang-Undang Nomor 28 Tahun 2014 Tentang Hak Cipta.

\section{UCAPAN TERIMA KASIH}

Terimakasih kami ucapkan kepada Direktorat Penelitian dan Pengabdian Masyarakat (DPPM) Universitas Muhammadiyah Malang yang mana telah memberikan fasilitas kepada tim pengabdi melaluikegiatan pengabdian masyarakat sehingga dapat terselenggara dengan sangat lancar. Terimakasih pula kami ucapkan kepada Kepala Sekolah SD Muhammadiyah 8 DAU Malang yang mana telah memberikan kesempatan serta menjalin kerjasama yang baik dengan tim pengabdian untuk memberikan penyuluhan hukum.

\section{DAFTAR PUSTAKA}

Endang Purwaningsih, Chandra Yusuf, Mohammad Ryan Bakry. (2019) Peningkatan Pengetahuan Hak Kekayaan Intelektual Guru-Guru Man 3 Jakarta Dalam Menumbuhkan Kesadaran Berkekayaan Intelektual. Jurnal Al-Ikhla.s. Volume 4 Nomor 2.

Fenty Ratnawati, (2015). Persepsi Siswa Terhadap Seni Batik Dan Upaya Guru Memperkenalkannya Sebagai Bentuk Warisan Budaya Indonesia Kepada Siswa Kelas V Sd Muhammadiyah 1 Blitar. Skripsi Program Studi Pendidikan Guru Sekolah Dasar Fakultas Ilmu Keguruan Dan Ilmu Pendidikan Universitas Muhammadiyah Malang 2015.

https://dgip.go.id/memahami-hak-cipta

Hukumonline.com. Artikel Dengan Judul "Penyuluh Hukum, Penyambung Suara Hukum Yang Harus Terus Berinovasi, Profesi Penyuluh Hukum Sangat Dibutuhkan Untuk Menyampaikan Materi Muatan Perundang-Undangan Dalam Bahasa Yang Mudah Dipahami Rakyat”. Dipublikasikan Selasa, 27 Agustus 2019 Diakses 25 September 2020.

Hukumonline.Com Penyuluh Hukum, Penyambung Suara Hukum Yang Harus Terus Berinovasi Profesi Penyuluh Hukum Sangat Dibutuhkan Untuk Menyampaikan Materi Muatan Perundang-Undangan Dalam Bahasa Yang Mudah Dipahami Rakyat.Dipublikasikan Selasa, 27 Agustus 2019 Diakses 25 September 2020.

Mirwansyah. Analisis Hukum Terhadap Tindak Pidana Hak Cipta (Di Tinnjau Dari UndangUndang Nomor 28 Tahun 2014 Tentang Hak Cipta). 